\title{
Maturation of Aldose Reductase Expression in the Neonatal Rat Inner Medulla
}

\author{
George J. Schwartz, * Beth J. Zavilowitz, " Anthony D. Radice, ${ }^{*}$ Arlyn Garcia-Perez, ${ }^{5}$ and Jeff M. Sands" \\ Departments of *Pediatrics and ${ }^{\ddagger}$ Molecular Genetics, Albert Einstein College of Medicine, Bronx, New York 10461; ${ }^{\S}$ Laboratory of \\ Kidney and Electrolyte Metabolism, National Heart, Lung and Blood Institute, Bethesda, Maryland 20892; and the \\ "Department of Medicine, Renal Division, Emory University School of Medicine, Atlanta, Georgia 30322
}

\begin{abstract}
Newborns are less able to concentrate urine than adults are. With development of the concentrating system and a hypertonic medullary interstitium, there is a need to generate intracellular osmolytes such as sorbitol, which is produced in a reaction catalyzed by the enzyme aldose reductase. We sought to discriminate between two possible mechanisms of aldose reductase induction during development: $(a)$ a response to an osmotic stimulus generated by the concentrating mechanism; or (b) part of the genetic program for development of the kidney. We measured the change in aldose reductase mRNA and activity in terminal inner medullary collecting ducts (IMCDs) microdissected from Sprague-Dawley rats during the first month of life. Aldose reductase mRNA was assayed by Northern analysis of total RNA from inner medulla and by detection of the reverse transcription-polymerase chain reaction (RT-PCR) product obtained from single IMCDs using aldose reductase-specific primers. Aldose reductase activity was measured in IMCDs taken from the same rats using a fluorescent microassay. Newborn rat IMCDs had minimal aldose reductase mRNA or activity, however mRNA was readily detected in IMCDs from rats older than $3 \mathrm{~d}$ of age, with peak expression occurring at 1-3 wk of age before decreasing to adult levels. In contrast, the mRNA level for a housekeeping metabolic enzyme, malate dehydrogenase, did not change during maturation. Aldose reductase enzyme activity was readily detectable by $6 \mathrm{~d}$ of age, peaked at 20 d, then decreased to adult levels. Urine osmolality remained $<600$ mosmol $/ \mathrm{kg}$ until $16 \mathrm{~d}$, then increased to $>1,100$ mos$\mathrm{mol} / \mathrm{kg}$ after $20 \mathrm{~d}$. Thus, aldose reductase mRNA and activity increased before urinary osmolality reached $870 \mathrm{mosmol} / \mathrm{kg}$. Because urine osmolality may not be indicative of inner medullary osmolality and because mother's milk may provide excessive free water to the pups under 3 wk of age, half of the animals in several litters were separated from their mothers for $1 \mathrm{~d}$ and inner medullary osmolality, in addition to urine osmolality, was measured by vapor pressure osmometry, while aldose reductase mRNA was assessed densitometrically in IMCDs after RT-PCR. Although fluid restriction resulted in a near doubling
\end{abstract}

Portions of this manuscript have been presented at the 24th Annual Meeting of the American Society of Nephrology, 17-20 November 1991, Baltimore, MD, and have been published in abstract form ( 1991 . J. Am. Soc. Nephrol. 2:766. [Abstr.]).

Address correspondence to Dr. Schwartz at his new address: Box 777, University of Rochester, 601 Elmwood Avenue, Rochester, NY 14642.

Received for publication 5 February 1992 and in revised form 24 March 1992.

J. Clin. Invest.

(c) The American Society for Clinical Investigation, Inc.

0021-9738/92/10/1275/09 \$2.00

Volume 90, October 1992, 1275-1283 of urine osmolality and a tendency towards increased aldose reductase mRNA, there was no consistently significant increase in aldose reductase mRNA or inner medullary osmolality during the first $\mathbf{1 3} \mathrm{d}$ of life compared to the suckling animals. On the other hand, 2-3-wk-old rats showed significant increases in aldose reductase mRNA, accompanied by increases in inner medullary osmolality, after fluid restriction. Thus, the dissociation between the increases in aldose reductase expression and inner medullary hyperosmolality indicates that the maturational induction of the aldose reductase gene is not a consequence of osmotic stimulation, but rather, part of the developmental program of the kidney. (J. Clin. Invest. 1992. 90:1275-1283.) Key words: aldose reductase - development • concentrating mechanism • malate dehydrogenase $\bullet$ osmoregulation

\section{Introduction}

The newborn has a limited ability to concentrate urine (1-3). Urine osmolality of neonatal rats rises from $300 \mathrm{mosmol} / \mathrm{kg}$ at birth to nearly $2,000 \mathrm{mOsm} / \mathrm{kg}$ by 3 wk of age (4-6). Papillary tip osmolality rises in parallel with the increase in urine osmolality, especially in animals deprived of mother's milk for 8-24 $h(7,8)$. Although rats being suckled ingest large amounts of free water, it is unlikely that this water loading inhibits the development of the concentrating system. Indeed, urinary concentrating ability is not accelerated by early weaning or delayed by prolonged suckling (9). Thus, the ability to generate a concentrated urine appears to be developmentally regulated. As the concentrating system matures and inner medullary tissue osmolality rises, the cells of the inner medulla need to accumulate osmotically active organic solutes for the maintenance and regulation of the intracellular milieu $(10,11)$.

A major intracellular osmolyte in the inner medulla is sorbitol (10-12), a polyhydric alcohol produced from D-glucose in a NADPH-dependent reduction reaction catalyzed by the enzyme aldose reductase (13). Sands et al. (14) showed that the highest levels of aldose reductase activity were found in the terminal half of the inner medullary collecting duct (terminal IMCD). ${ }^{1}$ Moreover, in response to water diuresis or antidiuresis, aldose reductase activity was regulated in this part of the nephron (15). This response appears to be controlled principally by changes in the rate of aldose reductase mRNA transcription (16-19). Recently, aldose reductase mRNA was detected in IMCD segments by the reverse transcription-polymerase chain reaction (RT-PCR) (20).

The maturational pattern of aldose reductase expression has not been investigated in the IMCD, although Bondy et al. (21) report that aldose reductase mRNA is not as abundant in

1. Abbreviations used in this paper: IMCD, inner medullary collecting ducts; MDH, malate dehydrogenase; RT-PCR, reverse transcriptionpolymerase chain reaction; $\mathrm{VRC}$, vanadyl ribonucleoside complex. 
newborn rat papilla as in mature papilla. The purpose of the present studies was to compare the pattern of maturation of aldose reductase expression in the terminal IMCD and the ability to concentrate the urine. This was done to determine whether the increase in aldose reductase expression was in response to the development of the concentrating system or, alternatively, was under the control of a genetically regulated developmental program.

\section{Methods}

Experimental animals. Sprague-Dawley rats were obtained as litters from Taconic Farms, Inc., (Germantown, NY) and raised in the Animal Facility of the Albert Einstein College of Medicine. Rat pups were fed mother's milk ad lib. until weaning, which occurred at $\sim 21 \mathrm{~d}$ postnatally, and were thereafter allowed free access to rat chow (Ralston-Purina, St. Louis, MO) and water. Some litters were divided randomly into two groups, one of which was left with the mother while the other was deprived of suckling and maintained for $20-24 \mathrm{~h}$ at $33 / 34^{\circ} \mathrm{C}$ to induce dehydration (5); each group generally contained three to five pups. Adults, fed an ad lib. diet, were studied at 2-3 mo of age.

The animals were anesthetized by intraperitoneal injection of sodium pentothal $(30 \mathrm{mg} / \mathrm{kg}$ body weight). Collagenase was used to partially digest kidneys to isolate IMCDs for aldose reductase enzyme assay and for some RT-PCR studies. In animals older than $15 \mathrm{~d}$ of age, the left kidney was selectively perfused, as previously described (14), with $10 \mathrm{ml}$ of ice cold dissection solution (see below), followed by 10 $\mathrm{ml}$ of the same solution, to which were added $1 \mathrm{mg} / \mathrm{ml} \mathrm{BSA}$ and 1 $\mathrm{mg} / \mathrm{ml}$ collagenase (type 1; Sigma Chemical Co., St. Louis, MO) (14). In younger rats, a 19-gauge butterfly needle was placed directly in the left ventricle to allow perfusion of the kidneys.

After perfusion the kidney was excised, cut coronally, and the papilla was transferred to a tube containing prewarmed dissection solution with collagenase and BSA, gassed with oxygen, and digested with gentle oxygen bubbling for $30-40 \mathrm{~min}$ at $37^{\circ} \mathrm{C}$. The incubated tissue was washed with cold dissection solution and stored on ice in dissection solution containing $10 \mathrm{mM}$ vanadyl ribonucleoside complex (VRC) (5 Prime 3 Prime, Inc., West Chester, PA) to inhibit RNA degradation (20).

Urine, plasma, and inner medullary osmolality. Urine was expressed from the pups' bladders by applying suprapubic pressure (4) before death and osmolality was measured by vapor pressure osmometry (model 5100B; Wescor Inc., Logan, UT). For the litters that were divided into suckling and nonsuckling (fluid restricted) groups, urine was obtained either before death or thereafter by bladder aspiration, and blood was collected into microcentrifuge tubes.

To obtain inner medullary tissue for osmolality, we sliced kidneys longitudinally to reveal the papillary tip (which did not protrude beyond the kidney during the first 2 wk of life). The terminal 1-2 mm of inner medulla was cut out of the kidney using forceps and vascular scissors under a dissecting microscope. Depending on the age, three to five of these inner medullary tips were blotted dry, placed on a $6.5-\mathrm{mm}$ diameter filter disc (Wescor), wrapped in clear plastic film wrap (Borden, North Andover, MA), and frozen on dry ice. Osmolality was measured on these tissues by vapor pressure osmometry (22) using an equilibration chamber that was specially designed to accomodate tissue (kindly provided by Dr. Mark Knepper, National Institutes of Health, Bethesda, MD). Calibrations were made using 290, 500, and 1,000 mosmol/ $\mathrm{kg}$ standards provided by the manufacturer. Collagenase digestion was not used in these studies because of the potentially detrimental effects on the maintenance of the papillary osmolality.

Preparation of total RNA from inner medulla. For Northern analysis (see below) the papilla was dissected on ice from a nonperfused kidney, homogenized for $\sim 15 \mathrm{~s}$ with an Ultra-Turrax (Janke-Kunkel; Tekmar Co., Cincinnati, $\mathrm{OH}$ ) using a S25N probe at $24,000 \mathrm{rpm}$ in guanidinium solution (containing $5 \mathrm{M}$ guanidinium isothiocyanate, 50
$\mathrm{mM}$ Tris- $\mathrm{HCl}, \mathrm{pH} 7.5,10 \mathrm{mM} \mathrm{Na}{ }_{2} \mathrm{EDTA}$, and $8 \%$ vol/vol $\beta$-mercaptoethanol at $7 \mathrm{ml} / \mathrm{g}$ tissue) (23). In 3- and 14-d-old animals, the whole inner medulla was processed, while in $22-d$ and adult animals, the terminal half of the inner medulla was used to prepare RNA. In mature rats, aldose reductase expression is highest in the terminal half of the inner medulla $(14,16)$.

RNA was precipitated from inner medullary homogenates using $\mathrm{LiCl}(23)$ and extracted two to three times in 1:1 Tris-saturated ( $\mathrm{pH} 8$ ) phenol CIA (where CIA is chloroform isoamyl alcohol 24:1), followed by two extractions in CIA, and precipitation at $-20^{\circ} \mathrm{C}$ in 0.1 vol $3 \mathrm{M}$ $\mathrm{Na}$ acetate plus 2.5 vol of ethanol (23).

Microdissection of IMCDs. In those kidneys for which IMCD segments were to be obtained for RT-PCR, the papilla, as well as the tubules, were microdissected at $17^{\circ} \mathrm{C}$ in dissection solution (containing in mM: $145 \mathrm{NaCl}, 2.5 \mathrm{~K}_{2} \mathrm{HPO}_{4}, 2.0 \mathrm{CaCl}_{2}, 1.2 \mathrm{MgSO}_{4}, 4.0 \mathrm{Na}$ lactate, $1.0 \mathrm{Na}_{3}$ citrate, $6.0 \mathrm{~L}$-alanine, and 5.5 glucose; $\mathrm{pH}$ was 7.4 and osmolality $290 \pm 2 \mathrm{mosmol} / \mathrm{kg}$ ) (24) plus $10 \mathrm{mM}$ VRC (20). Segments were dissected from the terminal half of the inner medulla, wherein the highest aldose reductase activity is found in mature rats (14). In newborn and very young rats, the inner medulla did not extend beyond the outlines of the coronal section and ranged in length from 1 to $2 \mathrm{~mm}$. In older animals, the inner medulla extended well beyond that limit and exceeded $4 \mathrm{~mm}$ in length by $20 \mathrm{~d}$ of age.

In general 1-2-mm segments, as measured using a calibrated eyepiece micrometer, were microdissected and used for each RT-PCR run; 2-3 mm were usually obtained for each enzyme assay. We collected four to eight tubules per animal for the aldose reductase assay and RT-PCR (see below).

Northern analysis of RNA from inner medulla. $20 \mu \mathrm{g}$ of total cellular RNA from each age group was size fractionated by electrophoresis on $1 \%$ agarose gels containing $3 \%$ formaldehyde and blotted overnight to nylon filters (Nytran; Schleicher \& Schuell, Inc., Keene, NH), which were baked at $80^{\circ} \mathrm{C}$ in vacuo for $1 \mathrm{~h}(25)$.

DNA probes were labeled with $\left[{ }^{32} \mathrm{P}\right] \mathrm{dCTP}$ to a specific activity of $1-5 \times 10^{8} \mathrm{cpm} / \mu \mathrm{g}$ by random hexanucleotide extension (Amersham Corp., Arlington Heights, IL). The filters were prehybridized for $2-4 \mathrm{~h}$ in $50 \%$ formamide at $37^{\circ} \mathrm{C}$ and then hybridized overnight in the same solution and temperature to which the labeled DNA probe was added. To probe for aldose reductase activity, we used the $1.3-\mathrm{kb}$ insert of the rabbit aldose reductase $\mathrm{CDNA}$, pAR 10 (19). After washing at $55-65^{\circ} \mathrm{C}$ with $0.1 \%$ SDS $/ 1 \times$ standard saline citrate (SSC) (where $20 \times$ SSC is 3 $\mathrm{M} \mathrm{NaCl}$ and $0.3 \mathrm{M} \mathrm{Na}_{3}$ citrate), the filter was exposed at $-80^{\circ} \mathrm{C}$ for $2-5$ $\mathrm{d}$ to Kodak XAR film. To assure that the RNA was of comparable quality from each animal, we removed the probe by washing the filter at $95^{\circ} \mathrm{C}$ in $0.1 \times \mathrm{SSC} / 0.1 \% \mathrm{SDS}$ for $15 \mathrm{~min}$ and then reprobed with a $1.2-\mathrm{kb}$ insert of the rat cDNA of a general metabolic enzyme, malate dehydrogenase (MDH) (26). The filter was exposed for $3 \mathrm{~d}$ at $-80^{\circ} \mathrm{C}$.

$R T$-PCR. RT-PCR was performed with modifications of the method described by Moriyama et al. (20). Rat aldose reductase-specific primers ( $25 \mathrm{mer}$ ) were prepared at the Albert Einstein College of Medicine Oligonucleotide Synthesis Facility and purified by ethanol precipitation in $2 \mathrm{M}$ ammonium acetate. The sequence of the antisense primer was 5'-CCCCCATAGGACTGGAGTTCTAAGC-3' and that of the sense primer was 5'-ACTGCCATTGCAAAGGCATCGTGGT$3^{\prime}(20)$.

Individual IMCD segments from at least 10 different litters were transferred to well dishes containing PBS plus $10 \mathrm{mM}$ VRC, rinsed twice in PBS and three times in PBS containing $5 \mathrm{mM}$ DTT and 0.7 U/ $\mu 1$ RNAse-inhibitor (RNAsin; Promega Corp., Madison, WI). The washed segment was transferred to a $0.5 \mathrm{ml}$ microcentrifuge tube containing $10 \mu$ l of Triton mix (composed of $2 \%$ Triton, $0.7 \mathrm{U} / \mu \mathrm{l}$ RNAsin, $5 \mathrm{mM}$ DTT) and frozen at $-80^{\circ} \mathrm{C}$ until use. Freezing allowed us to simultaneously compare IMCD segments from littermates of different ages and of different states of hydration.

To the tube containing Triton mix and 1-2 IMCD segments were added $2 \mu$ l diethylpyrocarbonate-treated (DEPC) water, $2 \mu \mathrm{l}$ of $10 \times$ PCR buffer (Promega), $2 \mu$ l deoxynucleotide mixture $(1.25 \mathrm{mM}$ stock of each nucleotide) (Pharmacia LKB Biotechnology, Inc., Pis- 
cataway, NJ), $1 \mu \mathrm{l}$ (40 U) RNAsin, $2 \mu$ l oligo(dT) ( 80 pmol; Pharmacia), $1 \mu \mathrm{l}(8 \mathrm{U} / \mu \mathrm{l})$ AMV reverse transcriptase (Promega) and reverse transcription proceeded at $42^{\circ} \mathrm{C}$ for $1 \mathrm{~h}$. The reverse transcriptase was inactivated by heating to $94^{\circ} \mathrm{C}$ for $5 \mathrm{~min}$, and the contents were cooled to $4^{\circ} \mathrm{C}$ before adding (in the same tube) $65.5 \mu \mathrm{l}$ DEPC water, $8 \mu 110 \times$ PCR buffer, $5 \mu$ l deoxynucleotide mixture, $0.5 \mu$ lantisense primer, 1.0 $\mu 1$ of sense primer ( $80-100$ pmols of each primer), and $0.5 \mu \mathrm{l}(2.5 \mathrm{U})$ Taq polymerase (Promega). Amplification was performed on a thermal cycler (MR Research, Inc., Watertown, MA) programmed as follows: initial melt at $94^{\circ} \mathrm{C}$ for $3 \mathrm{~min}$, then cycled $35-40$ times at $94^{\circ} \mathrm{C}$ for $1 \mathrm{~min}, 60^{\circ} \mathrm{C}$ for $1 \mathrm{~min}, 72^{\circ} \mathrm{C}$ for $2 \mathrm{~min}$, followed by a 7 -min final extension at $72^{\circ} \mathrm{C}$ and storage at $4^{\circ} \mathrm{C}(20) .20 \%$ of each sample was size fractionated by electrophoresis on a $2 \%$ agarose gel and PCR products were visualized by ultraviolet fluorescence after ethidium bromide staining.

RT-PCR was generally performed on 1-2 mm of terminal IMCD (300-1,000 cells). Comparisons of signal intensities of PCR products from IMCDs of different age groups or of different lengths from the same age group were always performed on tubules that were processed simultaneously for RT-PCR after freezing at $-80^{\circ} \mathrm{C}$. Tissue from untreated rats appeared to provide comparable signals to those observed from collagenase-treated kidneys (see Results).

When comparing expression from suckling and fluid restricted animals within the same litter, we obtained five to eight IMCD segments from the kidney of one animal in each group (the other animals were used to provide kidneys for measurement of inner medullary osmolality). Segments from both suckling and fluid restricted groups of the same litter were dissected on the same day and frozen. Batches of 10-30 segments were subjected to RT-PCR, along with two frozen aliquots of $0.5 \mu \mathrm{g}$ total RNA from adult rat kidney serving as controls. The RTPCR products were quantitated from the ethidium bromide-stained gels using a laser densitometer (Ultroscan XL; LKB Instruments, Inc., Gaithersburg, MD) (kindly loaned to us by Dr. Marshall Horwitz) (27). The values were normalized by tubule length and expressed as a percentage of the signal from the total RNA samples (28).

For another group of tubules, we divided the reverse transcribed cDNA into two parts and amplified half using aldose reductase-specific primers (as described above) and the other half using MDH-specific primers. The latter were derived from the nucleotide sequence of rat pre-MDH (26). The sequence of the sense primer (24-mer) was 5'CAAGAAGCATGGCGTATACAACCC- $3^{\prime}$ and that of the antisense primer (22-mer) was 5'-TTTCAGCTCAGGGATGGCCTCG-3'. Amplification of this MDH sequence was predicted to yield a product of $507 \mathrm{bp}$ in length, the intensity of which would serve as a basis for comparison to the aldose reductase-specific product by densitometry. The amplification conditions were the same as for aldose reductase, except that 45 cycles were used to generate products from the smaller amount of cDNA.

Southern analysis of RT-PCR products. Amplified DNA from the tubules on the mini-gel was denatured in alkali, neutralized, and blotted over $36 \mathrm{~h}$ to Nytran in $10 \times \mathrm{SSC}$, baked, and probed as described above with the rabbit aldose reductase cDNA. $30 \mathrm{~min}$ to $2 \mathrm{~h}$ of exposure of the filters at $-80^{\circ} \mathrm{C}$ was sufficient for detection of the signal.

Aldose reductase enzyme assay. Tubule segments were transferred to well dishes containing dissection solution, rinsed three times in dissection solution, and transferred to a microcentrifuge tube containing $25 \mu \mathrm{l}$ of $0.1 \% \mathrm{BSA}$ in water. The tubes were vortexed, quick-spun, and rapidly frozen in dry ice. They were maintained frozen at $-80^{\circ} \mathrm{C}$ until the time of assay. In preliminary studies, we found that segments dissected from kidneys that had not been previously digested with collagenase gave aberrantly low and inconsistent values for aldose reductase activity (data not shown).

The aldose reductase assay measures the amount of $\mathrm{NADP}^{+}$ formed when aldose reductase reduces the added in vitro substrate DL-glyceraldehyde $(14,15)$. With this method NADP ${ }^{+}$production is linear with incubation time and tubule length, and the reaction is specific for aldose reductase (14). After thawing, the tubules were incubated in a solution containing $10 \mathrm{mM} \mathrm{NaCl}, 60 \mathrm{mM} \mathrm{K}_{2} \mathrm{SO}_{4}, 50 \mathrm{mM}$
$\mathrm{KH}_{2} \mathrm{PO}_{4}, 10 \mathrm{mM}$ DL-glyceraldehyde, $0.25 \mathrm{mM}$ NADPH (pH 7.15; osmolality, $290 \mathrm{mosmol} / \mathrm{kg}$ ) at $37^{\circ} \mathrm{C}$ for $90 \mathrm{~min}$ in a shaking water bath (14). Next, $0.5 \mathrm{~N} \mathrm{HCl}$ was added to stop the reaction and destroy the remaining NADPH. After cooling, $6 \mathrm{~N} \mathrm{NaOH}$ was added, the tubes mixed thoroughly, and transferred to a $60^{\circ} \mathrm{C}$ shaking water bath for 30 min to maximize conversion of $\mathrm{NADP}^{+}$to its highly fluorescent condensed form (14). The tubes were cooled and fluorescence was measured in a manual spectrofluorimeter (model 450; Sequoia-Turner Corp., Mountain View, CA) with the excitation wavelength set to 360 $\mathrm{nm}$ and the emission wavelength set to $450 \mathrm{~nm}$. The amount of $\mathrm{NADP}^{+}$generated was determined from NADP ${ }^{+}$calibration curves. For each sample, aldose reductase activity was calculated in picomoles $\mathrm{NADP}^{+}$generated per minute incubation per millimeter tubule length ( $\mathrm{pmol} / \mathrm{min}$ per $\mathrm{mm}$ ).

Cell count. To determine if there was any maturational change in the number of cells per millimeter, $3 \%$ paraformaldehyde-fixed IMCD segments were obtained from newborn and 20-d-old rats and stained with the ultraviolet chromatin dye Hoechst 33258 (bisbenzimide; 10 $\mu \mathrm{g} / \mathrm{ml})(24)$. Nuclear counts at $500 \times$ were obtained in two to five $40-\mu \mathrm{m}$ sections of tubule and normalized by $1 \mathrm{~mm}$ tubular length. Also, the volume of each segment was calculated from the outer diameter and expressed as cubic millimeter per millimeter tubular length.

Statistics. Data are giveu as mean \pm SE. Multiple measurements per animal were averaged to provide a single value. All blots and amplifications were performed in duplicate using different tubules or RNA samples. Statistical analysis was performed using analysis of variance with multiple range test and Bonferonni's inequality. A value of $P<0.05$ was used to assert statistical significance.

\section{Results}

Changes in urinary osmolality with maturation. The urine osmolality of normal suckling rats did not exceed 400 mos$\mathrm{mol} / \mathrm{kg}$ during the first days of life, or $600 \mathrm{mosmol} / \mathrm{kg}$ by $18 \mathrm{~d}$ of life (Fig. 1). After $20 \mathrm{~d}$, there was a dramatic increase in urine osmolality, with most values exceeding 1,100 mosmol/ kg (Fig. 1).

Aldose reductase $m R N A$ expression in inner medulla. In agreement with previous studies $(16,21)$, aldose reductase mRNA expression was very low in kidney cortex and outer medulla of mature rats, but was much higher in the inner medulla (data not shown).

A maturational study of inner medullary aldose reductase mRNA indicated very low expression in 3-d-old rat inner medulla with increasing levels at 14 and $22 \mathrm{~d}$ postnatally (Fig. 2). The expression at maturity was somewhat less than that observed at $22 \mathrm{~d}$ (Fig. 2). Maturational studies of the control ("housekeeping") mRNA, MDH, indicated that the low ex-

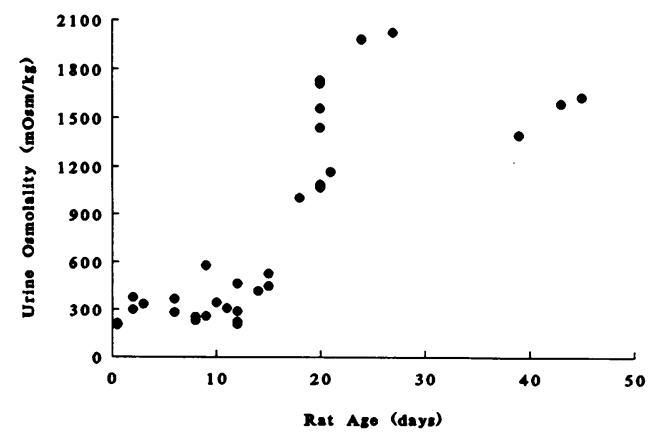

Figure 1. Urine osmolality as a function of age. Urine was obtained from the bladders of rats fed an ad lib. diet, and from pups fed mother's milk ad lib. 


\section{A

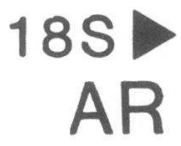

\section{3d 14d 22d adult}
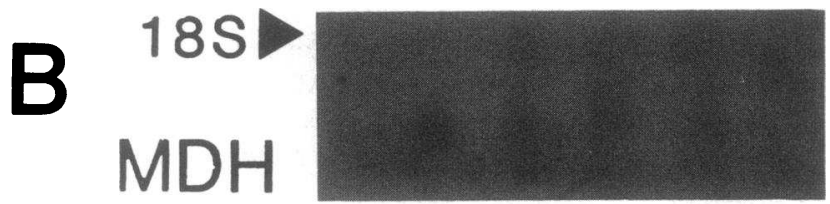

3d 14d 22d adult

Figure 2. Northern blot showing aldose reductase mRNA expression as a function of age. $20 \mu \mathrm{g}$ of total RNA from the inner medullas of 3-, 14-, and $22 \mathrm{~d}$, and adult rats were fractionated in each lane. The blot was originally hybridized to pAR 10 , shown above. The same blot was then rehybridized to malate dehydrogenase cDNA, shown below. The $18 \mathrm{~S}$ ribosomal RNA marker is located in each blot at the solid triangle. Expression of aldose reductase mRNA was minimal in the inner medulla of the 3- and 14-d-old rats. In contrast, the MDH mRNA expression was relatively constant during maturation. AR, aldose reductase.

pression of aldose reductase mRNA in the newborn was not attributable to RNA degradation or variable loading of the gel (Fig. 2).

To investigate this maturational pattern of aldose reductase mRNA expression required 40 kidneys from 3-d-old rats, and four kidneys from 14- and 22-d-old animals, a rather insensitive analysis. Moreover, we used the whole inner medulla (and not the terminal half) from the 3- and 14-day-old animals because of the limited amount of tissue available, and this may have resulted in dilution of the cells expressing aldose reductase mRNA and an apparently lower signal, especially for the 14-dold animals. Because of the high activity of the terminal IMCD (14), we chose to measure aldose reductase activity and mRNA levels in this specific segment during maturation.

Aldose reductase $\mathrm{MRNA}$ in IMCDs from maturing rats as detected by $R T-P C R$. The ethidium bromide-stained gels of RT-PCR product from microdissected terminal IMCDs taken from 3-d-old and 20-d-old rats showed increased signal with increasing tubular length (Fig. 3). Relative to the intensity of the comparably loaded DNA molecular weight markers, the signals from the 20 -d-old rats were more intense than those from the 3-d-old animals at any tubular length and were dependent on reverse transcriptase (Fig. $3 B$ ), indicating PCR amplification from cDNA rather than from genomic DNA (20).

To characterize the RT-PCR product, we transferred the DNA to filters and probed them with the pAR 10 aldose reductase cDNA. Fig. 4 shows increased aldose reductase expression in progressively longer tubules from an 8-d-old rat, indicating that 40 cycles did not extend the PCR amplification beyond the exponential phase (20). Also, it can be seen that the signal from a 1.8-mm IMCD segment from an 8-d-old rat was high and easily detectable, even though smaller than the signal derived from $0.5 \mu \mathrm{g}$ of total RNA from adult rat kidney. No RT-PCR product was observed in the absence of RNA or Taq polymerase.
When comparable lengths of IMCDs from the same litter were reverse transcribed and specifically primed and amplified by PCR, it can be seen that segments from 26-d-old rats expressed less PCR product than did those from 6-20-d-old rats, and that expression during the first day of life was nearly undetectable (Fig. 5). Furthermore, when the RT-PCR products from $1 \mathrm{~mm}$ of tubule were compared by ethidium bromide staining and Southern analysis, aldose reductase expression was highest in IMCDs from 6-20-d-old rats, less in segments from 26-d-olds, less in those from adult rats, and least in those from newborn rats (Fig. 6).

These results disagree somewhat with the Northern analysis (see Fig. 2, signal at $14 \mathrm{~d}$ was not as intense as from older animals), but were achieved from 1-2 mm of tubule (3001,000 cells) rather than from milligrams of tissue. The Northern analysis required RNA prepared from the whole inner medulla, which is a mixture of different nephron segments, including initial inner medullary collecting ducts that express little aldose reductase activity (14); the RT-PCR was accomplished with single collecting duct segments from the terminal inner medulla and thereby must be considered more indicative of the situation in the papillary tip. By comparing Figs. 1, 5, and 6, one finds that the increase in aldose reductase mRNA preceded the maturation of urinary concentrating ability.

The low expression of aldose reductase mRNA in IMCDs from 3-d-old animals, compared with that of older animals,
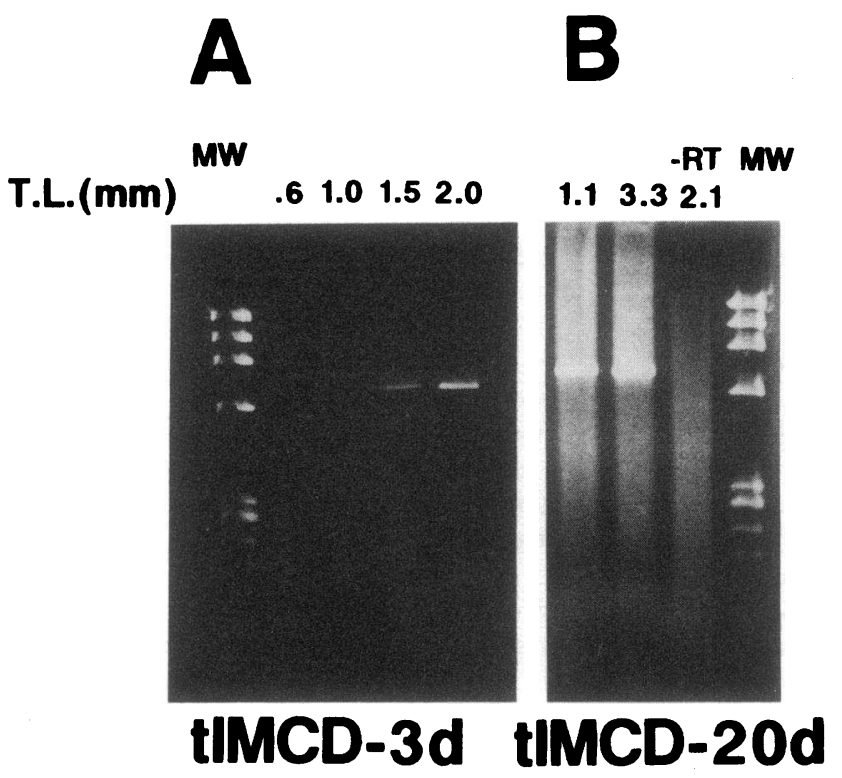

Figure 3. Product analysis of RT-PCR for aldose reductase mRNA in terminal IMCD segments isolated from 3- and 20-d-old rats and fractionated on $2 \%$ agarose gels stained with ethidium bromide. $(A)$ IMCDs from 3-d-old rat. Lane 1 shows molecular weight markers, from top to bottom (in basepairs) 1353, 1078, 872, 603, 310, 276, 234 , and 194. The aldose reductase product is located at $670 \mathrm{bp}$, as expected (20). (B) IMCDs from 20-d-old rat. In lane 3, the segment was handled identically, except that reverse transcriptase was omitted. Lane 4 shows the same molecular weight markers. The expression of aldose reductase was not detectable in 1-mm segments from 3-d-old rats, but was found in similar sized segments from 20-d-old rats, increased with increasing tubular length, and was dependent on reverse transcription. T.L., tubular length. 


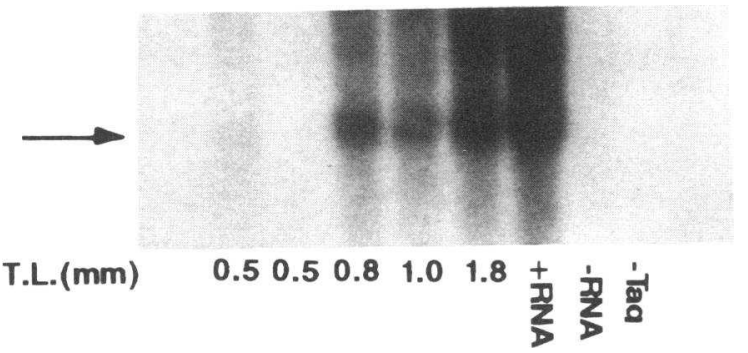

Figure 4. Southern analysis of products from RT-PCR of IMCD segments taken from 8-d-old rat probed with pAR10. The arrow denotes the location of the aldose reductase product. Lanes 1-5 show varying lengths of IMCDs. Control run in lane 6 shows product from RTPCR of $0.5 \mu \mathrm{g}$ of total RNA from adult rat kidney; those in lane 7 (no total RNA) and lane 8 (no Taq polymerase) show no product. Increasing length resulted in increased product, which was dependent on the presence of RNA and Taq polymerase. RT-PCR product was easily seen with $0.8-1 \mathrm{~mm}$ of tubule ( $300-400$ cells).

could be attributed to more rapid degradation of the RNA or to artifacts in the amplification of cDNA from the younger rats. Therefore, we simultaneously reverse transcribed the RNA from IMCDs of two different ages and amplified half of each sample for aldose reductase cDNA and the other half for a housekeeping cDNA, MDH. From Fig. 7, it is evident that $\mathrm{MDH}$ expression was comparable in 2-mm IMCDs from 2and 25-d-old rats, while aldose reductase expression was markedly less in the younger animal. The densitometric ratio of aldose reductase to MDH was 0.25 in the IMCD from the 2-d-

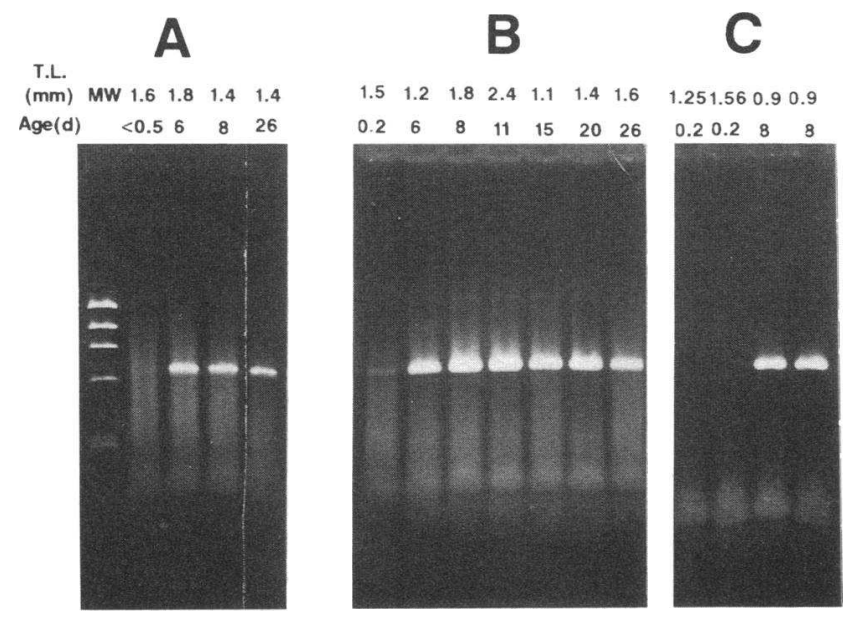

Figure 5. Product analysis of RT-PCR for aldose reductase from IMCD segments obtained from maturing rats and run on a $2 \%$ agarose gel. $(A)$ RT-PCR performed on terminal IMCD segments obtained from one litter of rats whose kidneys were not subjected to collagenase digestion. Lane 1 shows molecular weight markers from top to bottom (in bp): 1353, 1078, 872, 603, 310, 276, 234, and 194. The major PCR product is found at $670 \mathrm{bp}$. (B) RT-PCR performed on terminal IMCD segments obtained from another litter of rats whose kidneys were subjected to collagenase digestion and whose terminal IMCD segments were also assayed for aldose reductase activity (see Fig. 9). ( $C$ ) RT-PCR performed on additional IMCD segments from litter presented in $(B)$. Peak expression was observed between 6 and $20 \mathrm{~d}$ of age; expression in the first day of life was nearly undetectable.

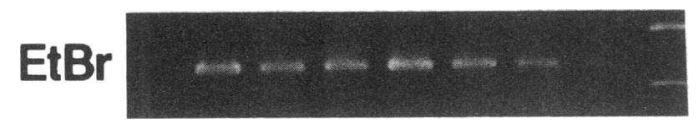

\section{Southern}

$$
\begin{aligned}
& \text { T.L. }(\mathrm{mm}) 1.1 \quad 1.0 \quad 1.1 \quad 1.0 \quad 0.91 .00 .8 \quad 0.9 \mathrm{MW}
\end{aligned}
$$

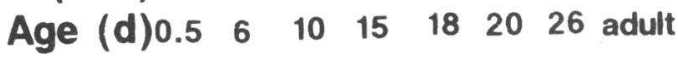

Figure 6. Product and Southern analysis of RT-PCR for aldose reductase from IMCD segments obtained from rats throughout maturation and run on $2 \%$ agarose gel. $(A)$ RT-PCR performed on terminal IMCD segments obtained from rats without collagenase digestion yielded a single product at $670 \mathrm{bp}$. Lane 9 shows 872 and $603 \mathrm{bp}$ markers. $(B)$ Southern analysis of products visualized by ethidium bromide at top and probed with pAR 10. A single product is seen on this 30-min exposure, from $6 \mathrm{~d}$ to maturity. Definite but minimal expression was detected in the newborn (this was better visualized on the 2-h exposure of the autoradiogram, not shown). Maximal expression was seen at $6 \mathrm{~d}$, but expression remained high through $20 \mathrm{~d}$ of age, before declining at $26 \mathrm{~d}$. Aldose reductase expression at maturity was also less than observed at 6-20 d.

old compared with 0.44 in that from the 25 -d-old rat. From four separate runs, the mean aldose reductase/MDH ratio was $0.14 \pm 0.07(n=3)$ in 2-3 d old rat IMCDs compared with $1.04 \pm 0.25(n=5)$ in IMCDs from 17-35-d-old rats $(P<0.05)$.

Aldose reductase activity in IMCDs isolated from maturing rats. The foregoing data would indicate that the abundance of aldose reductase mRNA increases during the first week of life, peaks between 1 and 3 wk of age, and then stabilizes at the lower adult levels. We therefore assessed aldose reductase activity in isolated segments of terminal IMCDs obtained from the same litter of rats used to prepare Fig. $5 B$ and $C$ to correlate changes in enzyme activity with steady state mRNA expression. As can be seen in Fig. 8, aldose reductase activity rose gradually before peaking at $20 \mathrm{~d}$ of age; levels in both newborns, 26-d-olds and adults were significantly less than peak values. By comparing Figs. 1 and 8 , one finds that the increase in aldose reductase activity occurred before the maturation of urinary concentrating ability.

Because the tubules were larger later in maturation, it was possible that normalizing enzyme activity by tubular length would not be the best standard for comparison. Accordingly, we corrected aldose reductase activity by tubular volume and by number of cells. In six IMCDs from 0.2-2-d-old rats, the outer diameter and cell counts per millimeter were significantly less than observed in four IMCDs from 20-d-old rats (outer diameter in $\mu \mathrm{m}: 24.9 \pm 1.8$ vs. $34.5 \pm 1.0$; cells per mm: $326 \pm 26$ vs. $488 \pm 33$ ). The estimated volume of $1 \mathrm{~mm}$ of IMCD was $4.87 \times 10^{-4} \mathrm{~mm}^{3}$ in the newborn compared with 9.34 $\times 10^{-4} \mathrm{~mm}^{3}$ in the 20-d animals. From Fig. 9, it can be seen that the aldose reductase activity per millimeter IMCD of 20-dold rats was 16.6 times that of neonates, and that correction by cell number ( 11.1 times) or tubular volume ( 8.7 times) did not account for the higher activity of the segments from 20-d-old rats. Clearly, there was increased aldose reductase activity with maturation. 
Effect of fluid restriction on the development of urine and inner medullary osmolalities and on aldose reductase gene expression. The interpretation of our results could be obscured by two potential flaws in the experimental design: first, we used urine osmolality as a measure of inner medullary osmolality, which is the ultimate regulator of aldose reductase expression in the adult $(12,13,16,19)$; and second, because the pups were suckling mother's milk, it was possible that they were ingesting excess free water, which might reduce urine and probably inner medullary osmolality, thereby resulting in an apparent delay in the development of aldose reductase gene expression.

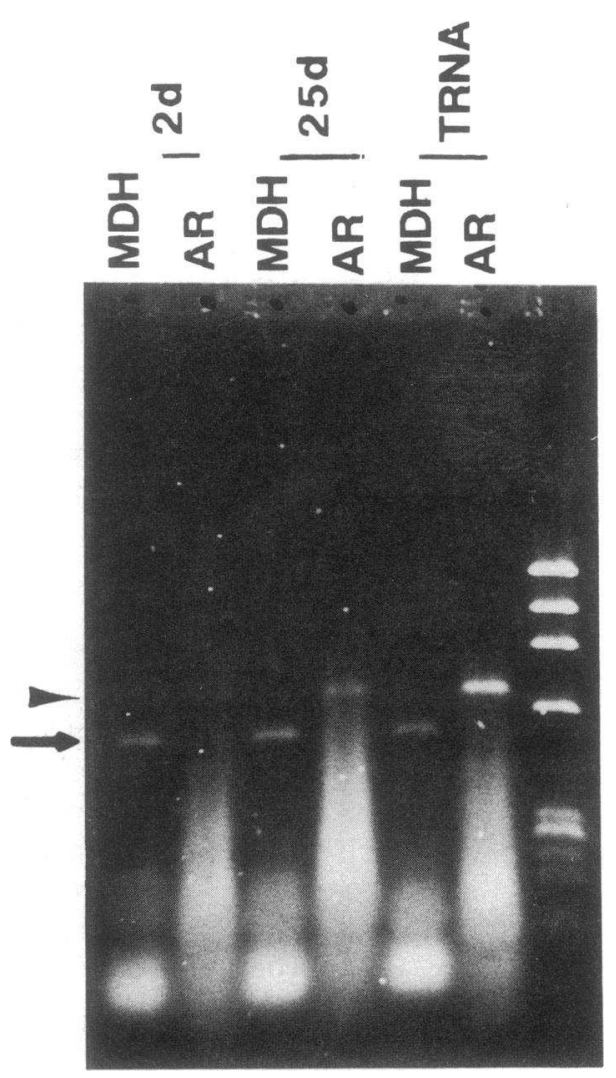

Figure 7. Product analysis of RT-PCR for MDH and aldose reductase $(A R)$ from IMCD segments obtained from 2-d-old rat ( $2.1 \mathrm{~mm}$, lanes $l$ and 2 ) and 25-d-old rat ( $1.6 \mathrm{~mm}$, lanes 3 and 4), compared with positive control obtained from $0.5 \mu \mathrm{g}$ of total RNA from mature rat kidney (lanes 5 and 6). Molecular weight markers, as described in Fig. 5, are present in lane 7. The expression of MDH (arrow) at $\sim 500$ bp was approximately constant for the IMCDs taken from 2 and $25 \mathrm{~d}$ (raw densitometric readings 0.32 and 0.30 , respectively), whereas there was little aldose reductase expression (arrowhead) by the 2-d-old segment relative to the 25-d-old (raw densitometric readings 0.078 and 0.130 , respectively). The $A R / M D H$ ratio was 0.25 in the 2 -d-old IMCD vs. 0.44 in the 25 -d-old segment, indicating that the low expression of aldose reductase in the newborn was not caused by degradation of the RNA or faulty reverse transcription or amplification of the cDNA. In control experiments with total RNA from rat kidney, eliminating reverse transcriptase or Taq polymerase resulted in the appearance of no MDH RT-PCR product on the ethidium bromide-stained gel (not shown). Also, increasing total RNA from 0.2 to $1.0 \mu \mathrm{g}$ gave a more intense band on the ethidium bromidestained gel (not shown), indicating that MDH RT-PCR was log-linear at 45 cycles.

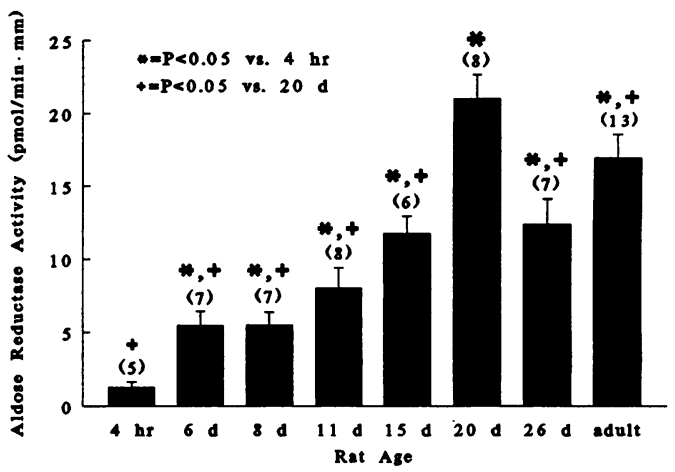

Figure 8 . Aldose reductase activity ( $\mathrm{pmol} / \mathrm{min}$ per $\mathrm{mm}$ ) in terminal IMCD segments isolated from maturing rats. Means are given by the height of the bars, SE by the length of the tics extending therefrom; numbers of segments studied are given in parentheses. The value from 20-day-old rats was significantly greater than that from adults and newborns.

To address these problems, we divided several litters into two groups on the day before study: Suckling animals (controls) were left with their mothers, while fluid restricted pups were separated from their mothers for 20-24 h. The next day, blood, urine, and inner medullary tissue were obtained from some animals, and from a separate animal, the inner medulla was dissected free using RNAse-free techniques to provide tissue for RT-PCR of terminal IMCD segments.

During the first 2 wk of life, urine and inner medullary osmolalities did not equilibrate in control animals (Fig. 10), with urine osmolality being $\sim 50 \%$ of inner medullary osmolality. Fluid restriction brought urine and inner medullary osmolalities much closer to equilibration, but not $>800 \mathrm{mosmol} / \mathrm{kg}$ (Fig. 10), despite a 5-10\% body wt loss during the $24-\mathrm{h}$ period. On the other hand, the 19-d-old rats had higher control urine and inner medullary osmolalities and the pups deprived of water showed osmolalities approaching adult levels of 2,000 mosmol $/ \mathrm{kg}$. There were no significant changes in plasma osmolality induced by fluid and food restriction at any age (data not shown).

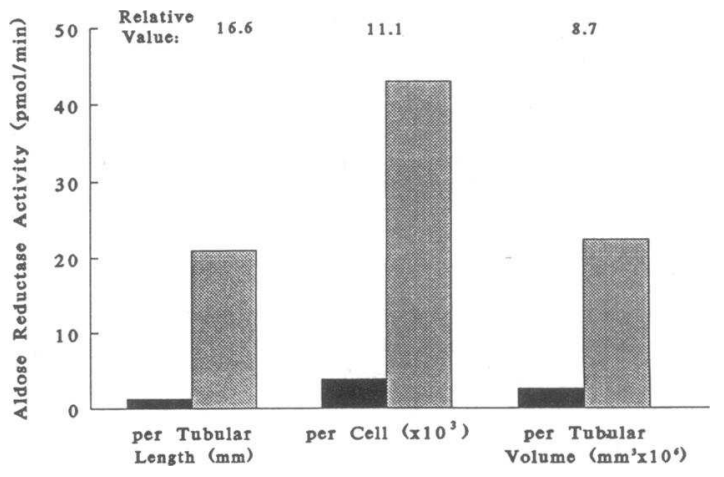

Figure 9. Aldose reductase activity ( $\mathrm{pmol} / \mathrm{min}$ ) in terminal IMCD segments from 4-h and 20-d-old rats. Aldose reductase activity was normalized by tubular length (left bars), cell number (center bars), and cell volume (right bars). Regardless of normalization method, aldose reductase activity was higher in 20-d-old rat segments than in newborn tissue $\mathrm{a}, 4 \mathrm{~h}$ old; 0 , $20 \mathrm{~d}$ old. 


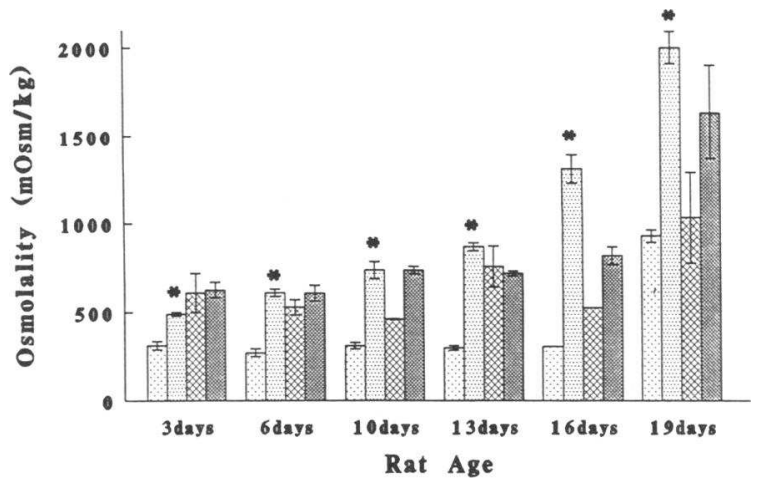

Figure 10. Urine and inner medullary osmolalities in suckling and antidiuretic littermates during maturation. At each age group, the bars depict mean urine osmolality of control rats, and of antidiuretic rats, and mean inner medullary osmolality of control and experimental rats, respectively. The SE ranges were generally determined from three to nine urines and two to four samples of inner medulla $\left(^{*}, P\right.$ $<0.05$, suckling vs. antidiuretic urine osmolality; the low numbers of assays of inner medullary osmolality, pooled from several animals, did not allow statistical analysis). At every age, the urine osmolalities obtained after fluid restriction were significantly higher than after suckling and were equilibrated with inner medullary osmolalities; control urines were always less than inner medullary osmolalities. Antidiuresis did not result in urine or inner medullary osmolalities exceeding $870 \mathrm{mosmol} / \mathrm{kg}$ until after $2 \mathrm{wk}$ of age. $\mathrm{g}$, urine osmolality (control); $\square$, urine osmolality (diuretic); $:$, inner medullary osmolality (control); $\mathbf{a}$, inner medullary osmolality (diuretic).

Fluid restriction caused urine osmolality to double at all ages during maturation, consistently exceeding $1,300 \mathrm{mosmol} /$ $\mathrm{kg}$ by $16-17 \mathrm{~d}$ of age (Fig. 10,11). On the other hand, aldose reductase $\mathrm{mRNA}$ (RT-PCR product normalized by $1 \mathrm{~mm}$ tubular length) tended to increase in IMCDs of fluid restricted animals at all ages, but the changes were significant only at 14 and $17 \mathrm{~d}$ of age (Fig. 11). Furthermore, the aldose reductase mRNA levels were highest during the second week of life, well before the urine osmolality exceeded $800 \mathrm{mosmol} / \mathrm{kg}$ (Fig. 11). A representative run shows the variability of fluid restriction-induced stimulation of aldose reductase expression (Fig. 12). Thus, the expression of aldose reductase mRNA was induced while the inner medullary osmolality was relatively dilute and while the animals were ingesting excess free water. These are clearly not the conditions that stimulate aldose reductase expression in mature animals $(10,12,13,15,19)$.

\section{Discussion}

Our major findings are that aldose reductase mRNA increases dramatically during the first and second weeks of postnatal life, the increase in mRNA is associated with an increase in aldose reductase activity, and that these changes occur before the maturation of the urinary concentrating mechanism. The increases in aldose reductase mRNA and aldose reductase activity are likely to be caused, at least in part, by increased gene transcription. The increase in aldose reductase before the production of a concentrated urine suggests that this transcriptional activity was stimulated by an undefined developmental signal that is distinct from changes in osmolality. Thus, in the immature kidney, it appears that the mechanism for accumulation of at least one organic osmolyte is set in place before the maturational increase in inner medullary hyperosmolality.

Associated with the maturation of the concentrating system during the first 3 wk of postnatal life in the rat are increased urine osmolality ( see Fig. 1) (4, 6, 7), vascularization and cytodifferentiation of the inner medulla, and lengthening of the papilla ( 7,8 , and data not shown), which includes the long loops of Henle and the inner medullary collecting ducts. These changes lead to development of a corticopapillary osmotic gradient, and intracellular osmolytes become important for maintenance of cellular functions in this concentrated milieu. A major cell osmolyte is sorbitol, which is produced from glucose via aldose reductase. As first shown by Bondy et al. (21), there is little aldose reductase mRNA in the inner medulla of the neonatal rat (Fig. 2). More specifically, we have shown that there was little mRNA or activity in IMCD segments isolated from the neonatal terminal inner medulla (see Figs. 2, 3, 5-9, 11,12 ).

During the second week of postnatal life, before the major increase in urinary concentration, there was evidence for increased aldose reductase mRNA in IMCDs obtained therefrom, as well as increased aldose reductase activity in isolated IMCDs (compare Figs. 1 and 5-8, 10,11). Bondy et al. used in situ and Northern hybridization analyses to show that aldose reductase expression was low at birth and increased at $12 \mathrm{~d}$ of age, but the cell-specific expression of the gene was not evident from their sections (21). Our studies show that the terminal IMCD was a major segment expressing aldose reductase mRNA and activity throughout the maturational process.

By $20 \mathrm{~d}$ of life, when the concentrating system was fully developed, IMCDs obtained from the terminal inner medulla showed high aldose reductase mRNA levels (Figs. 5 and 6) and peak activities (Fig. 8). The correlation between IMCD mRNA levels (as estimated from RT-PCR) and single segment

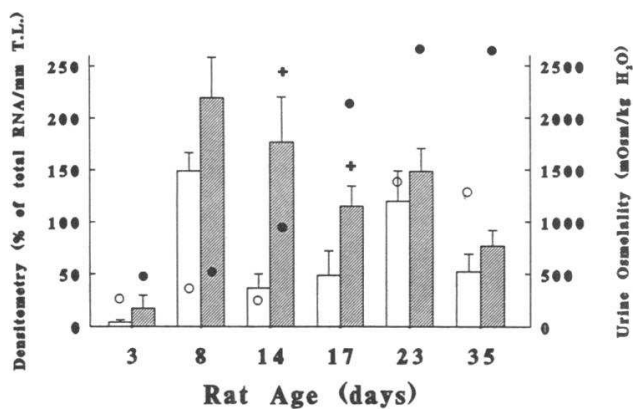

Figure 11. Densitometric analysis of IMCDs taken from suckling (control) and antidiuretic (experimental) rats during maturation. The bars indicate the mean plus SE of the densitometric readings, factored by $1 \mathrm{~mm}$ tubular length (T.L.) and normalized by percentage of values obtained from simultaneous run of two samples of $0.5 \mu \mathrm{g}$ total RNA prealiquoted from rat kidney and quantified at OD $260 \mathrm{~nm}$. T.L. ranged from 0.9 to $1.2 \mathrm{~mm}$. The dots represent urine osmolalities obtained from the rats providing the IMCD segments, with a calibration presented on the right side of the figure. No urine was obtained from the control animal at $17 \mathrm{~d}$ of age. Peak expression of aldose reductase was noted at $8 \mathrm{~d}$ of age; expression was stimulated at all ages by water deprivation, but the increases were only significant at 14 and $17 \mathrm{~d}$ of age $(+P<0.05$ compared to segments from paired suckling littermate). $\square$, control densitometry; $\mathbf{m}$, experimental densitometry; $\bigcirc$, control urine osmolality; $\bullet$, experimental urine osmolality. 

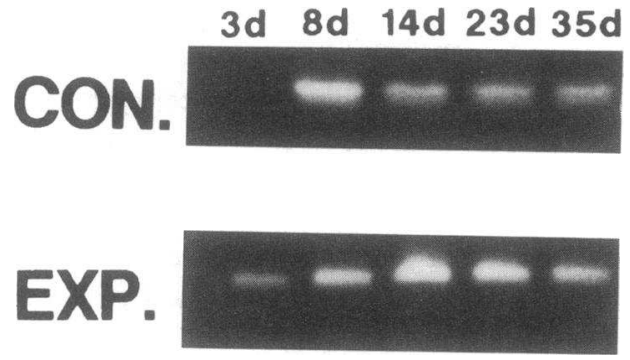

Figure 12. Representative aldose reductase RT-PCR run of IMCDs taken from paired suckling (control) and antidiuretic (experimental) rats during maturation. Segments ranged in length from 0.9 to 1.1 $\mathrm{mm}$. Fluid restriction appeared to increase the product in segments from 3-, 14-, and 23-d-old rats, but not in those from 8- and 35-d-old rats. Each of six runs was analyzed densitometrically, as summarized in Fig. 11.

aldose reductase activity suggested that changes in aldose reductase mRNA levels play a major role in preparing the cells for the synthesis of intracellular sorbitol; however, this mRNA appeared to be stimulated by a nonosmolar factor because it was increased before the corticopapillary osmotic gradient fully developed (compare Figs. 1 and 5-8, 10, and 11).

Note that weaning occurs at $\sim 21 \mathrm{~d}$ of age, such that aldose reductase activity has matured before the rats switch their diets from mother's milk to solid food plus water. It is unlikely that dietary modifications influenced the maturation of aldose reductase activity because mRNA levels were already high at 6-14 d, well before the rats attempt to wean. Previous studies have confirmed that premature weaning at $14-16 \mathrm{~d}$ failed to perceptively affect the histological structure of the kidney (29) or induce early maturational increases in urine osmolality after $24 \mathrm{~h}$ of fluid and food deprivation (9). We did see increased aldose reductase mRNA (following restriction of suckling) in terminal IMCDs from rats of all ages, but these increases were only significant in 14 and $17 \mathrm{~d}$ old rats. The latter result contrasts with a previous study showing that $72 \mathrm{~h}$ of water restriction did not stimulate aldose reductase activity in inner medullary homogenates from adult rats (16).

Bondy et al. showed that aldose reductase gene expression was higher in papillas from 12-d-old rats than from mature rats (21). We expanded this maturational study and showed peak expression to be at 6-20 d postnatally; both mRNA and enzyme activity were less in IMCDs from older rats (see Figs. 5-8, 11 , and 12). From the correlation between single segment RTPCR and aldose reductase activities, it appeared that this decline in synthesis was pretranslationally controlled. Presumably, with the maturation of the concentrating system, enzyme synthesis was only necessary to maintain steady state levels of aldose reductase, as determined from the enzyme turnover (12). Additionally, in inner medullary collecting duct cells, intracellular osmolyte accumulation exerts a negative feedback on aldose reductase mRNA and enzyme synthesis $(12,17$, $19,30)$.

In many situations, changes in papillary osmolality can induce changes in aldose reductase synthesis $(12,13,15,16,21)$. The mechanism for osmotic induction of aldose reductase gene transcription is unclear $(12,13,16,21)$, but increased intracellular ionic strength appears to be the distal signal (31). During development, with the increase in aldose reductase expression preceding the achievement of a concentrated urine and not being well correlated with an increase in inner medullary osmolality, it is likely that some other form of transcriptional control is being elaborated. The developmental biology of this genetic regulation represents an important area for further investigation.

\section{Acknowledgments}

We thank Dr. Mark Knepper for providing the equilibration chamber for measurement of inner medullary osmolalities and Dr. Marshall Horwitz for allowing us the use of his laser densitometer. We are grateful to Drs. M. Burg, S. Emmons, W. Mitch, and A. Spitzer for their encouragement and support. This work was supported by National Institutes of Health grants HD-13232 (to G. J. Schwartz) and R29DK41707 (to J. M. Sands). Dr. Sands was an Established Investigator of the American Heart Association during the performance of these studies.

\section{References}

1. Calcagno, P. L., M. I. Rubin, and D. H. Weintraub. 1954. Studies on the renal concentrating and diluting mechanisms in the premature infant. J. Clin. Invest. 33:91-96.

2. Edelmann, C. M., Jr., H. L. Barnett, and V. Troupkou. 1960. Renal concentrating mechanisms in newborn infants. Effect of dietary protein and water content, role of urea, and responsiveness to antidiuretic hormone. J. Clin. Invest. 39:1062-1069.

3. Winberg, J. 1959. Determination of renal concentrating capacity in infants and children without renal disease. Acta. Paediatr. 48:318-328.

4. Falk, G. 1955. Maturation of renal function in infant rats. Am. J. Physiol. 181:157-170.

5. Heller, H. 1949. Effects of dehydration on adult and newborn rats. $J$. Physiol. (Lond.). 108:303-314.

6. McCrory, W. W., Jr. 1972. Developmental Nephrology. Harvard University Press, Cambridge, MA. 123-161.

7. Edwards, B. R., D. B. Mendel, F. T. LaRochelle, Jr., P. Stern, and H. Valtin. 1982. Postnatal development of urinary concentrating ability in rats: changes in renal anatomy and neurohypophysial hormones. In The Kidney During Development. Morphology and Function. A. Spitzer, editor. Masson Publishing, New York. 233-239.

8. Trimble, M. E. 1970. Renal response to solute loading in infant rats: relation to anatomical development. Am. J. Physiol. 219:1089-1097.

9. Rane, S., A. Aperia, P. Eneroth, and S. Lundin. 1985. Development of urinary concentrating capacity in weaning rats. Pediatr. Res. 19:472-475.

10. Garcia-Perez, A., and M. B. Burg. 1990. Importance of organic osmolytes for osmoregulation by renal medullary cells. Hypertension (Dallas). 16:595-602.

11. Yancey, P. H., and M. B. Burg. 1989. Distribution of major organic osmolytes in rabbit kidneys in diuresis and antidiuresis. Am. J. Physiol. 257:F602-F607.

12. Garcia-Perez, A., and M. B. Burg. 1991. Renal medullary organic osmolytes. Physiol. Rev. 71:1081-1115.

13. Burg, M. B. 1988. Role of aldose reductase and sorbitol in maintaining the medullary intracellular milieu. Kidney Int. 33:635-641.

14. Sands, J. M., Y. Terada, L. M. Bernard, and M. A. Knepper. 1989. Aldose reductase activities in microdissected rat renal segments. Am. J. Physiol. 256:F563-F569.

15. Sands, J. M. and D. C. Schrader. 1990. Coordinated response of renal medullary enzymes regulating net sorbitol production in diuresis and antidiuresis. J. Am. Soc. Nephrol. 1:58-65.

16. Cowley, B. D., Jr., J. D. Ferraris, D. Carper, and M. B. Burg. 1990. In vivo osmoregulation of aldose reductase mRNA, protein, and sorbitol in renal medulla. Am. J. Physiol. 258:F154-F161.

17. Smardo, F. L., Jr., M. B. Burg, and A. Garcia-Perez. 1992. Kidney aldose reductase gene transcription is osmotically regulated. Am. J. Physiol. 262:C776C782.

18. Moriyama, T., A. Garcia-Perez, and M. B. Burg. 1989. Osmotic regulation of aldose reductase protein synthesis in renal medullary cells. J. Biol. Chem. 264:16810-16814.

19. Garcia-Perez, A., B. Martin, H. R. Murphy, S. Uchida, H. Murer, B. D. Cowley, Jr., J. S. Handler, and M. B. Burg. 1989. Molecular cloning of cDNA coding for kidney aldose reductase: Regulation of specific mRNA accumulation by NaCl-mediated osmotic stress. J. Biol. Chem. 264:16815-16821. 
20. Moriyama, T., H. R. Murphy, B. M. Martin, and A. Garcia-Perez. 1990. Detection of specific mRNAs in single nephron segments by use of the polymerase chain reaction. Am. J. Physiol. 258:F1470-F1474.

21. Bondy, C. A., S. L. Lightman, and S. L. Lightman. 1989. Developmental and physiological regulation of aldose reductase mRNA expression in renal medulla. Mol. Endocrinol. 3:1409-1416.

22. Knepper, M. A. 1982. Measurement of osmolality in kidney slices using vapor pressure osmometry. Kidney Int. 21:653-655.

23. Cathala, G., J.-F. Savouret, B. Mendez, B. L. West, M. Karin, J. A. Martial, and J. D. Baxter. 1983. A method for isolation of intact, translationally active ribonucleic acid. DNA. 2:329-335.

24. Schwartz, G. J., J. Barasch, and Q. Al-Awqati. 1985. Plasticity of functional epithelial polarity. Nature (Lond.). 318:368-371.

25. Brion, L. P., J. H. Schwartz, H. M. Lachman, B. J. Zavilowitz, and G. J. Schwartz. 1989. Development of $\mathrm{H}^{+}$secretion by cultured inner medullary collecting duct cells. Am. J. Physiol. 257:F486-F501.

26. Grant, P. M., J. Tellam, V. L. May, and A. W. Strauss. 1986. Isolation and nucleotide sequence of a cDNA clone encoding rat mitochondrial malate dehydrogenase. Nucleic Acids Res. 14:6053-6066.

27. Fredman, J. N., S. C. Pettit, M. S. Horwitz, and J. A. Engler. 1991. Linker insertion mutations in the adenovirus preterminal protein that affect DNA replication activity in vivo and in vitro. J. Virol. 65:4591-4597.

28. Terada, Y., T. Moriyama, B. M. Martin, M. A. Knepper, and A. GarciaPerez. 1991. RT-PCR micro-localization of mRNA for guanylyl cyclase-coupled ANF receptor in rat kidney. Am. J. Physiol. 261:F1080-F1087.

29. Boss, J. M. N., H. Dlouha, M. Kraus, and J. Krecek. 1963. The structure of the kidney in relation to age and diet in white rats during the weaning period. $J$. Physiol. (Lond.). 168:196-204.

30. Bondy, C., B. D. Cowley, Jr., S. L. Lightman, and P. F. Kador. 1990. Feedback inhibition of aldose reductase gene expression in rat renal medulla. Galactitol accumulation reduces enzyme mRNA levels and depletes cellular inositol content. J. Clin. Invest. 86:1103-1108.

31. Uchida, S., A. Garcia-Perez, H. Murphy, and M. Burg. 1989. Signal for induction of aldose reductase in renal medullary cells by high external $\mathrm{NaCl} . \mathrm{Am}$. J. Physiol. 256:C614-C620. 